\title{
Saudi Arabia Charity and the Institutionalization of Indonesian Salafism ${ }^{1}$
}

\author{
Jajang Jahroni \\ State Islamic University (UIN) Syarif Hidayatullah Jakarta \\ email:jajang.jahroni@uinjkt.ac.id
}

\section{Abstract}

[This article primarily discusses the links between Saudi Arabian Islamic charity organizations and the development of Salafism in Indonesia and how these links facilitate the institutionalization of Salafi groups. It specifically deals with the issues of how Islamic charity help Salafi groups create their institutions and how the Salafis distribute these charities to their own members. It also describes how they managed to survive when the flow of Saudi funds was no longer reliable. The primary focus of this article is on the way Islamic charity and Islamic charity organizations respond to existing social and political conditions by engaging in social and political activism. International Islamic charity organizations have shaped the transformation of Islamic movements over the last decades. Indonesian Salafi groups have benefitted from charities in various ways and they have enabled Salafi groups to create their institutions in Indonesia. It is no exaggeration to say that Indonesian Salafi groups have become the major players in the distribution of Saudi Arabian charities in the country. This process is inescapably linked with politics which further shapes the transformation of Salafism in Indonesia.

Pembahasan utama artikel ini adalah menjelaskan keterbubungan antara lembaga amal Arab Saudi dengan perkembangan kelompok Salafi di Indonesia dan bagaimana bubungan ini memfasilitasi penguatan organisasi

1 Parts of this articles are based on my dissertation chapter which I defended at the Department of Anthropology of Boston University on May 2015. I have updated some new informations to it in order to be easily understood. 
Jajang Jahroni

kelompok tersebut. Lebih khususnya adalab bagaimana lembaga amal Islam tersebut membantu mendirikan yayasan serta membagi dana tersebut kepada anggota-anggotanya. Selain itu juga menjelaskan bagaimana yayasan yang terbentuk itu bertahan ketika tidak lagi menerima sumbangan dari Arab Saudi. Intinya adalah tulisan ini menjelaskan cara kerja filantropi Islam dan organisasi amalnya merespon kondisi sosial dan politik dengan terlibat dalam aktifisme. Organisasi filantropi Islam internasional pada dasarnya telah membawa transformasi gerakan Islam lebih dari satu dekade terakhir. Kelompok Salafi Indonesia dengan berbagai cara telah mengambil keuntungan dari dana amal ini dan untuk menguatkan organisasi mereka di Indonesia. Tidak berlebihan jika disebut bahwa kelompok Salafi merupakan pemain utama dalam distribusi dana amal ini di Indonesia. Proses ini merupakan hal yang tak bisa dibindarkan dari kaitan politik dimana telah banyak berpengaruh pada trasnformasi Salafisme di Indonesia.]

Keywords: Saudi Arabia, Salafism, Wahhabism, Indonesia, Charity, Institution

\section{A. Introduction}

In the early 1970s, Saudi Arabia sent its special envoy, Abd alAziz al-Ammar, to Indonesia. He was a student of Abdullah Bin Baz (1910-1999), the Saudi grand mufti and the most respected contemporary Saudi ulama. The purpose of his visit was to discuss the possibility of cooperation between the two countries. In Jakarta, al-Ammar was welcomed by Mohammad Natsir (1908-1993), the prominent Muslim figure and former leader of the Masyumi, the largest Islamic political party during the Soekarno era. After the dissolution of the Masyumi in 1960, Natsir made a deliberate move from politics to social activism. He founded the DDII (Dewan Dakwah Islam Indonesia-Indonesian Council for Islamic Promulgation), an organization concerned with da'wah (Islamic promulgation) and Islamic education. ${ }^{2}$ Apart from that, he also developed international relations with Muslim countries, especially Saudi Arabia, and he became active in its international bodies. The al-Ammar-Natsir

2 On DDII, see Asna Husin, "Philosophical and Sociological Aspects of Da'wah: A Study of Dewan Dakwah Islamiyah Indonesia", PhD. Dissertation (New York: Columbia University, 1998). 
encounter was extremely important as it shaped the further direction of the Islamic movement at home. ${ }^{3}$

A few years later, an Islamic college specializing in Sharia and Arabic was founded in Jakarta and al-Ammar was appointed as its director. Even though there was a controversy about the issue, the college was eventually established. ${ }^{4}$ The college was officially part of the University of Imam ibn Saud of Riyadh. In practice, however, al-Ammar had set up the whole thing, from its curriculum, students' admission regulations, teacher recruitment, and, most importantly, networking with local Islamic organizations. Natsir supplied al-Ammar with students as many DDII cadres were urged to study at this college. Promising students were given scholarships to pursue advanced degrees in Saudi Arabia. From the beginning, being close to Natsir, al-Ammar's political stand favored modernist groups and he hardly involved traditionalists. ${ }^{5}$

Apart from working with Natsir, al-Ammar was highly dependent on the Hadhrami, local ethnic Arabs originating from the Hadhramawt, Yemen, who served as intermediary groups between the Saudis and the Indonesian Muslim population. His encounter with the Hadhrami groups further shaped the process of Salafism's transformation to Indonesia. Throughout his career, al-Ammar made frequent travels across the country to extend his network and to search for strategic locations for establishing Saudi foundations. He married a local woman and had a family. In the mid-1980s, he was sent back home and was appointed as a high official at the Ministry of Hajj and Waqf, a Saudi institution which channeled donations to Muslim countries. Occupying this strategic

${ }^{3}$ Noorhaidi Hasan, Laskar Jihad: Islam, Militancy, and the Quest for Identity in Post-New Order Indonesia (Ithaca: Cornell University Press, Southeast Asia Program Publications at Cornell University, 2006), pp. 47-54.

4 On the controversy of the establishment of LIPIA, see Mujiburrahman, Feeling Threatened: Muslim-Christian Relations in Indonesia's New Order (Amsterdam: Amsterdam University Press, 2006), p. 138.

5 Martin van Bruinessen, "Ghazwul Fikri or Arabization? Indonesian Muslim Responses to Globalization", in Southeast Asian Muslims in the Era of Globalization, ed. by Ken Miichi and Omar Farouk (Tokyo: Japan International Cooperation Agency Research Institute (JICA-RI), 2013), pp. 47-70; Din Wahid, "Nurturing Salafi manhaj A study of Salafi pesantren in contemporary Indonesia", PhD. Dissertation (Utrecht: Utrecht University, 2014), p. 86. 
position, his connection with various Muslim groups in Indonesia was intensified. He instructed nascent Salafi groups in the country to create formal organizations, through which Saudi donations could legally be transferred. ${ }^{6}$

\section{B. The Oil Revenues and Saudi Arabia Foreign Policies}

Saudi Arabia foreign policies on education and the distribution of its charity will not be possible without the oil revenue. It is oil that makes Saudi prominent and influential within the Muslim world. Starting from Saudi Arabia and then spreading out to the Gulf States, the oil revenues spilled over many Muslim countries. A great amount of these revenues has been used to help fellow Muslims in Asia and Africa who lived in poverty or were the victims of conflicts. ${ }^{7}$ This marked a new era of international Islamic charity which helped Islamic organizations in many parts of the world to enable them to create their institutions particularly madrasa (Islamic schools) and mosques. The abundance of Islamic charities facilitated the construction of madrasa and mosques and revitalized their roles within the Muslim community, which had seriously diminished in the nation-state period. The presence of international Saudi Arabia Islamic charities facilitated Islamic movements that emerged in many Muslim countries. These movements range from those concerned with civil rights that were engaged in social activism, supporting the agendas of nation-states which suffered from a lack of financial or human resources. ${ }^{8}$ At the same time, the presence of charities also facilitated the rise of Muslim revivalist groups around the Muslim world that are concerned with reordering the Muslim community and its religious practices based on orthodox Islamic teachings, and with charity funds they built their madrasa and mosques and promoted a form of Islam which condemned religious innovations. The provision of Islamic charity thus had far-reaching consequences. In some countries, where the state was less effective, it led to the rise of radical groups professing various

6 Ahmad Attamimi, interview (20 Mar 2013).

7 Millard Burr and Robert O. Collins, Alms for Jihad: Charity and Terrorism in the Islamic World (Cambridge: Cambridge University Press, 2006), p. 27.

8 Hilman Latief, "Islamic Charities and Social Activism: Welfare, Dakwah and Politics in Indonesia”, PhD. Dissertation (Utrecht: Utrecht University, 2012), pp. 74-128. 
ideological and political goals. The rise of Hamas, established in 1987 in the Occupied Territories with the aim of liberating Palestine, was made possible by the abundant provision of charity funds. Collecting charities from international Muslim communities, Hamas used them to erect public facilities such as schools and hospitals. The escalation of the conflicts in the Gaza Strip prompted militancy within the Hamas factions. This is especially true when it came to have a military wing called Izz al-Din al-Qassam Brigade, in 1991. Hamas was subsequently categorized as a terrorist organization by the Western authorities.' In this context, it is important to look at Jonathan Benthall's argument, a British anthropologists who made extensive research on Islam charity organization, that Islamic charities "pursued a mixture of humanitarian, religious, political, and sometimes military aims." 10

The rise of Salafism is part of a forceful revival of religion, which marked the turning of the millennium. ${ }^{11}$ This fact started from political unrest, which occurred in Saudi Arabia in the 1979. In the aftermath of the Grand Mosque seizure by religious extremists in 1979, the kingdom enforced accommodative Islam. Accommodative Islam is a project in which the state uses Islamic symbols to accommodate the religious establishment. In return, the religious establishment, or the ulama, provides legitimacy for the continuation of the house of al-Saud. The Saudi state refurbished and renovated religious sites, established Islamic colleges specializing on Sharia at home, and distributed educational aids abroad.

The institutionalization of Salafism in Indonesia was made possible with the generosity of Saudi charity contributing especially to the first step of its formation. The returning students who previously studied at Saudi universities helped its distribution. Through charities they created Salafi communities in the country by forging networks with local Islamic

9 See, for instance, Ziyād Abū 'Amr, Islamic Fundamentalism in the West Bank and Gaza: Muslim Brotherhood and Islamic Jihad (Bloomington: Indiana University Press, 1994); Robert W. Hefner, Civil Islam: Muslims and Democratization in Indonesia (Princeton: Princeton University Press, 2000).

10 J. Benthall, "The Overreaction against Islamic Charities", ISIM Review, vol. 20, no. 1 (2007), pp. 6-7.

11 José Casanova, Public Religions in the Modern World (Chicago: University of Chicago Press, 1994). 
Jajang Jahroni

organizations. Thanks to these charities, Salafis were able to create their institutions, particularly madrasa and mosques, two strategic institutions in Islam, through which they could reach wider Muslim audiences.

\section{International Saudi Arabia Charity in the Modern Period}

Saudi Arabia is the Muslim country with the largest Islamic charity organizations. ${ }^{12}$ Through its international bodies, it attempts to extend its political influence over other Muslim countries as well as to promote Wahhabism. It is relevant to note that Saudi Arabia was concerned with developments in the Islamic Republic of Iran which would avowedly export its revolution. In response to this, Saudi forged various networks with predominantly Sunni Muslim countries to intercept Iran's infiltration. One of the strategies the Saudi adopted was through charity organizations. It has created dozens of international bodies to channel charities, funds, grants, and other forms of humanitarian aid. It is clear that the kingdom used charity as a political tool leading to the rise of a Pax Saudica while it brought the Sunni world in the grasps of Wahhabism. ${ }^{13}$

There are at least three Saudi Arabian organizations to be highlighted here: Rabithah Alam Islami (World Muslim League-WML), IIRO (International Islamic Relief Organization), and WAMY (World Association of Muslim Youth). Established in 1962, WML has representatives in other Muslim countries. Through this organization, Saudi Arabia seeks to unite the Muslim world under its leadership. Its secretary general, responsible for administering day-to-day organizational policies, at present Muhammad ibn Abd al-Karim Issa, has always been a Saudi citizen. Through WML, Saudi Arabia challenges the secular NAM (Non-Aligned Movement) that seems to have lost its leadership position in the post-Nasser era. Its main task is to discuss the manifold problems the Muslim world faces particularly on education and public policies. It has published and distributed millions of copies of the Holy Qur'an with an English translation as well as other Islamic books including those written by Saudi ulama, all over the Muslim world. Through its consultative

12 Burr and Collins, Alms for Jihad, pp. 26-47.

13 Mona Abaza, 'M. Asad Shahab: A Portrait of an Indonesian Hadrami Who Bridged the Two World', in Southeast Asia and the Middle East: Islam, Movement, and the Longue Durée, ed. by Eric Tagliacozzo (Singapore: NUS Press, 2009), pp. 250-74.2009 
commission, which consists of senior ulama, MWL is authorized to issuing fatwa (religious edict) on specific religious issues. In 1974, it issued a fatwa against the Ahmadiyah asserting that it is considered a non-Muslim sect. Having an international reputation, its fatwa have become references for all Muslim groups across the globe. Bearing this in mind, the MWL is the most strategic Saudi Arabian institution to control the Sunni Muslim world under the guidance of Saudi Salafism. ${ }^{14}$

The second is IIRO, which is part of WML. Established in 1978, IIRO is expected to play an important role in humanitarian programs. ${ }^{15}$ It has organized humanitarian programs in Asia and Africa, helping fellow Muslims who are the victims of natural disasters, wars and political conflicts. Like other Saudi charity organizations, many IIRO officials are in fact Saudi ulama charged with offering advice on its programs. As a result, programs like Qur'anic instruction are included in IIRO programs. It channels financial support to erect mosques and madrasa in Asia and Africa. Its roles in Afghanistan gave birth to the rise of the Taliban, young Afghan students who, having completed their studies in Saudi Arabian schools became Wahhabism's mouthpiece. In many countries, IIRO is allowed to create local branches, allowing the infusion of Salafism to penetrate even deeper into the Muslim population. In Indonesia, IIRO created networks with various modernist Muslim organizations with similar religious orientations.

The last Saudi Arabian international body which exerts strong influence on the Muslim population is WAMY. Established in 1972, this organization is concerned with Muslim youth and aims to preserve their Muslim identities. Part of WML, this organization serves as a strategic institution to win the hearts and minds of the young Muslim generation. Having members in 60 countries, it seeks to guard the young Muslim generation from the waves of Western cultural domination as well as to protect Sunni youths from the Iranian-Shiite propaganda. In its heyday in the 1990s, it attracted many promising Muslim students in order to hold conferences and symposiums, conduct research and execute exchange programs. It annually invites students from all over the Muslim world

14 Burr and Collins, Alms for Jihad, pp. 33-4.

15 Ibid., p. 35; Jonathan Benthall and Jérôme Bellion-Jourdan, The Charitable Crescent: Polites of Aid in the Muslim World (London; New York: I.B. Tauris, 2003), p. 11. 
to perform the haij and the umrah (small pilgrimage). Its presence has inspired youth movements all over the world. ${ }^{16}$

On a second level there are a number of organizations whose task is to bridge the Saudi Arabian government and the Indonesian Muslim populations. These foundations have wide networks with local Islamic organizations that have become the recipients of their charity. They are run by professionals, many of whom having degrees in finance and economics and have close ties with the royal families. Their appointments should be with, and through, the endorsement of the royal families and the Saudi religious establishment. Officials who fail to abide to the rules may be fired and deported from the country. There are at least eleven major organizations that play important roles in distributing Saudi charities in Indonesia. ${ }^{17}$ Most of them are located in Java (Jakarta, Yogyakarta, and Surabaya), and one is located in Makassar, South Sulawesi. As will be shown below, Java has played an important role in the process of the transformation of Salafism in Indonesia. Meanwhile Makassar has experienced strong Islamic movements over the last decades.

At the very end of this structure are Salafi preachers and teachers. They are the last chain of the transmission of Salafism among the Indonesian Muslim population. Their physical appearance is striking as they usually wear the Saudi thawb, having long beards and putting the hems of their pants up above their ankles. According to some sources, Salafi preachers, especially those who are attached to Saudi institutions, are well paid. For this reason, they can fully concentrate on their jobs as preachers and teachers. During the heydays of Saudi charity, roughly around the 1990s, their payments were even much higher than those of Indonesian civil servants. In the early 2000s, along with the issuance of the contra-terrorism act which hampered the flow of international funds, their payments were significantly reduced. This raised suspicion among the preachers and led to fragmentation. ${ }^{18}$

16 Burr and Collins, Alms for Jihad, pp. 41-3.

17 Nidaul Fitrah in Surabaya, al-Huda in Bogor, al-Sofwa in Jakarta, al-Sunnah in Cirebon, al-Taifah al-Mansurah in Kediri, Markaz al-Faruq in Jember, Da'wah Islamiyah in Rangkas Bitung, Wahdah Islamiyah in Makassar, al-Imam in Sukabumi, Darun Najwa in Jakarta, and Eldata in Jakarta. Ahmad Attamimi, interview (20 Mar 2013).

18 Ibid. 


\section{Patron-Client Relationship between the Donors and the Beneficiaries}

The distribution of charity is highly political. The donors will select the beneficiaries of their charities based on certain criteria. The first and the foremost criteria is that the beneficiaries should be compliant and supportive to the political interests of the donors. Based on this criteria, the distribution of charity implies patron-client relationship between the donors and the beneficiaries. Through its officials, Saudi Arabia charity organizations select and distribute its charities. In the context of Indonesia, the Hadharamis have been selected as the beneficiaries as well as the distributors of Saudi Arabia charities. It is widely known that the Hadhramis have been intermediaries for a long time. During the Dutch colonial era, they had served as intermediaries between the Dutch and the inlanders.

In the context of the distribution of Saudi charities, the Hadhramis use certain codes to avoid jealousy between those who get the charities and those who do not.

Minna aw minhum? (Are they our friends or their friends?) is an expression to denote religious groupings among the Indonesian Muslim community. This code has been widely used by the Hadharamis. During the 1960s and 1970s, various Muslim organizations widely used this expression to set themselves apart from non-loyalists who might destroy their organizations from within. It resembles an internal code through which internal members communicate with each other. Non-members or outsiders who do not know Arabic may not understand the meaning of this expression. During the heyday of politik aliran (politics of ideology) in Indonesia, when tensions and suspicion among social and religious groups were extremely high, each created its own secret codes to prevent taping by the opponents. ${ }^{19}$

During my fieldwork in 2010-2012, I heard this expression again from my informant Hifni who previously worked as an official at a Saudi Arabia charity organization in Jakarta. Every time he received a proposal, he asked his staff. "Minna aw minbum?" If the proposals were made by minna, they were put in different folders for further consideration. If they were made by minbum, they were thrown away. He further explained that

19 Mujiburrahman, Feeling Threatened, p. 339. 
this means that minna proposals were made by Salafi organizations. He could quickly see whether a proposal was minna or minbum. Most of the Salafi proposals would be favorably considered and granted as long as they met the requirements and provided funds were still available. On the contrary, non-Salafi proposals would be turned down.

Syamsuddin, a Salafi teacher and friend of Hifni's told a similar story. In the early 2000s, not long after he had moved to Bogor, about fifty kilometers to the South of Jakarta, some villagers came to his house. They wanted him to help them to build their own mosque. Along with the rapid increase of the population, the villagers felt that it was necessary to build a mosque for their own community. This idea had come up a long time ago. A local donor had already endowed a piece of land but due to lack of funds, the idea had never materialized. Syamsuddin told them to make a proposal and to complete it with the land ownership certificate and some photos. When the proposal was ready, Syamsuddin took it to Hifni who just had a brief look at it and then agreed. In the coming weeks, after verifying all the documents, Hifni sent some of his staff to the location and expressed the foundation's agreement to building a new mosque. He said that although the distance between the new and the old mosque was less than one kilometer as stipulated, due to the dense population on the site, this requirement could be waved.

To avoid conflict with other Muslim groups, Salafi foundations require that the distance between an old and a new mosque should be at least one kilometer. But in practice, this distance can be ignored with the presence of, among others, dense populations. According to Hifni, the proposal was granted as Syamsuddin had guaranteed it. Syamsuddin then promoted Salafi da'wah among the local population. This task became much easier given the fact that he was an on-site Salafi teacher. Hifni said that many mosques to which his foundation had contributed funds, gradually escaped from their control due to the absence of onsite preachers. Local populations were generally opposed to Salafi da'wah because they did not have appropriate understanding on it. Apart from this unanticipated situation, the success of a fund request was largely determined by informal connections, which include shared ethnic origin, ideologies, and organization. In addition, more than any other group, the role of the Hadhramis in distributing Saudi charities was extremely 
prominent.

\section{E. The Hadhrami Connections}

Compared with other ethnic groups, Hadhramis enjoy better relations with Saudi officials at least for two reasons. First, Hadhramis have a long reputation as intermediaries. Second, both Hadhramis and Saudis share many cultural similarities. The term Hadhrami refers to people originating from Hadhramawt, an ancient region in southern Yemen. For centuries they lived in a diaspora stretching from East Africa in the west, through the Indian sub-continent up to Southeast Asia in the east. They had migrated to find a better life but also to promote Islamic propagation. The Hadhramis are well known for their prominence in commerce, religious authority, and statesmanship. In each country they created settlements in coastal areas which they then turned into business centers, schools, and religious institutions. ${ }^{20}$

Claiming to be the descendants of the Prophet Muhammad as reflected in their titles sayyid (pl. sada or sadat), they occupy high positions in the social order. ${ }^{21}$ Their lineages, skills, and social mobility ensured that their reputation remained unchallenged. Western colonial authorities were concerned with the Hadhramis' prominence. In Indonesia, due to their strategic leverage, they had been appointed as intermediaries, bridging the gaps between the colonial administration and the native Muslim population. One Hadhrami figure who enjoyed a great privilege under colonial patronage was Sayyid Uthman ibn Yahya, a Hadhrami mufti from Batavia and advisor for native affairs to the Dutch East Indies government. ${ }^{22}$

The Hadhrami community frequently suffered from internal

20 On the Hadhramis, see, for instance, Ulrike Freitag and William G. ClarenceSmith (eds.), Hadhrami Traders, Scholars and Statesmen in the Indian Ocean, 1750s to 1960s (Leiden, New York and Koln: Brill, 1997); Eric Tagliacozzo (ed.), Southeast Asia and the Middle East: Islam, Movement, and the Longue Durée (Singapore: NUS Press, 2009).

21 Sylvaine Camelin, "Reflections on the Sytem of Social Stratification in Hadhramaut", in Hadhrami Traders, Scholars and Statesmen in the Indian Ocean, 1750s to 1960s, ed. by Ulrike Freitag and William G. Clarence-Smith (Leiden, New York and Koln: Brill, 1997), pp. 147-56.

22 Azyumardi Azra, "Hadrāmī scholars in the Malay-Indonesian Diaspora: A Preliminary Study of Sayyid 'Uthmān”, Studia Islamika, vol. 2, no. 2 (1995), pp. 1-33. 
conflicts. This is because it is a highly stratified community, and the sada have been, and remain, the most important social and religious group. In the beginning of the twentieth century, the prominence of the sada came to be challenged by non-sada. The latter argued that marriages between non-sayyid men and sayyidah women were legitimate. They came up with this idea to counteract the application of kafa'ah which stipulated that a sayyidah can only be married by a sayyid. The issue of kafa' abled to a longstanding conflict between the Hadhrami communities in Indonesia and deep conflicts between both groups erupted leading to their division along social and political lines. The sada created the Jami'at al-Khair, while the non-sada created al-Irshad. Both organizations were active in education and social activities. In independent Indonesia, both organizations went through a period of serious decline as different political stands and ideological rivalries had major impact on the organizations. ${ }^{23}$

The venture of the Hadhramis was continued in the period of nation-state formation. A group of Hadhramis decided to support modern Indonesia by establishing the PAI (Partai Arab IndonesiaIndonesian Arab Party) thus severing their emotional identification with their homeland. ${ }^{24}$ Others maintained their relations with their home country and experienced a downturn in 1967 when the People's Democratic Republic of Yemen (South Yemen) was declared. The socialist regime confiscated many Hadhrami properties at home without offering any compensation. In the aftermath of the communist coup in 1965, many Hadhramis left Indonesia and moved to Malaysia, Singapore, or returned to Yemen. The rise of power of Saudi Arabia and the Gulf States as a new regional economic entity caused new patterns of migration, attracting many Hadhramis from all over Indonesia to migrate. ${ }^{25}$

The incorporation of the Hadhramis into the Saudi Arabian state was prioritized. Cultural similarities between the Hadhramis and the

23 Natalie Mobini-Kesheh, The Hadrami Awakening: Community and Identity in the Netherlands East Indies, 1900-1942 (Ithaca: Cornell Southeast Asian Program Publications-Cornell University Press, 1999), pp. 231-48.

24 Ibid., pp. 139-45.

25 William G. Clarence-Smith, "Hadhramaut and the Hadhrami Diaspora in the Modern Colonial Era: An Introductory Survey", in Hadhrami Traders, Scholars and Statesmen in the Indian Ocean, 1750s to 1960s, ed. by Ulrike Freitag and William G. Clarence-Smith (Leiden, New York and Koln: Brill, 1997), pp. 1-18.. 
Saudis made the migration process easier compared to non-Hadhramis such as Javanese and members of other Indonesian ethnic groups. These new groups of Hadhramis met their fellows who had lived in Mecca, Medina, and Jeddah for centuries. In these cities, there has always been a sizeable Yemeni-Saudi population. Some families such as that of Bin Ladin successfully created their construction businesses in Saudi. In the early 1970s, Indonesian modernist Muslim organizations successfully approached the Saudi Arabian government to promote its education system beyond its territorial border. At that time, the Hadhramis were not involved. It had been an exclusive initiative of Mohammad Natsir, the internationally renowned Indonesian Muslim leader. He approached Saudi Arabia in an attempt to revive its international bodies and to resume support to Muslim groups in Indonesia. Once the connection was established, however, the Hadhramis gradually took over the project and controlled it for the benefit of their own groups.

The success of contemporary Hadhramis in distributing Saudi charities to Indonesian Muslim groups has been going on for generations. Sayyid Muhammad Asadullah, born in Batavia in 1910, is a prototype of a person of Indonesian-Hadhrami origin who, in the aftermath of the abortive coup in 1965, sought refuge in a Saudi Arabian state institution. After having completed his education and because of his language skills, he worked in the Saudi Arabian Embassy in Jakarta. In the late 1960s, he moved to Saudi Arabia and he worked there as a journalist. He travelled extensively to Europe, Asia, and Southeast Asia and became what Abaza calls "a hybrid intellectual, the go-between different cultures of the Muslim world." ${ }^{26}$ Living apart from his relatives who lived in many parts of Indonesia, he regularly visited Jakarta to look up young Hadhrami students. He enticed many of them to study in Saudi Arabia and he helped them to find jobs after they had finished their studies. Although he was educated within a Hadhrami madrasa, he used to be uninterested in Salafism or any other form of Islamic puritanism. Working in Saudi Arabian international bodies, however, he gradually became one of its staunchest supporters, and his political standing can be read in every piece he wrote. He believed that Saudi Arabia was a great Islamic country,

26 Abaza, "M. Asad Shahab: A Portrait of an Indonesian Hadrami Who Bridged the Two World”, p. 250. 
which had succeeded to the leadership over other Muslim countries in the aftermath of the decline of the Ottoman Empire.

Another pattern of a Hadhrami connection may be found in the profile of Salim Segaf al-Jufri, the grandson of Habib Idrus al-Jufri, the founder of al-Khairat, an Islamic organization established in 1930 in Palu, Central Sulawesi. ${ }^{27}$ Born in Surakarta, Central Java in 1954, Salim Segaf al-Jufri obtained his early education under the tutelage of his grandfather. In 1972, he went to study at the Islamic University of Medina and he specialized in Sharia. Completing his doctoral degree in 1986, he returned to Indonesia and became a teaching staff at Saudi Arabia College (LIPIA) in Jakarta. According to Ahmad Zaini, a former college administrator, he was among the few Indonesian scholars who were well paid by the college. It was clear that the college highly respected al-Jufri's deep knowledge and his sada background, which seems to have been the reasons behind his appointment as a key figure in Saudi Arabian international bodies. From 1990 to 2000, he was appointed the representative of WAMY and IIRO for Southeast Asian Countries. With this strategic position, he used these bodies to support Islamic organizations in Indonesia, many of which belonged to the Hadhramis. Based on this historical precedence, it is hardly surprising that the Hadhramis were able to dominate the distribution of Saudi charities in Indonesia. Therefore, they shaped the transformation of Salafism, intermingled with the conflicts and disintegration pertinent to their history. Factionalism within the Hadhrami groups shaped the reproduction of Salafism and gradually took Salafism into another direction.

\section{F. Salafism Derailed}

Even though Saudi Arabia has international charity organizations, in general they are poorly administered and managed. There are three reasons for this. First, the distribution of Islamic charity is largely based on trust, which is in danger of being manipulated or misused by its recipients. Its distribution lacks preliminary assessments, has weak or wrong targets, and has insufficient standard operating procedures.

27 Martin Slama, "Translocal Networks and Globalisation within Indonesia: Exploring the Hadhrami Diaspora from the Archipelago's North-East”, Asian Journal of Social Science, vol. 39, no. 2 (Brill, 2011), pp. 238-57. 
Second, in many countries where Saudi charity organizations operate, the distribution of charity is made by bypassing local authorities, which in turn leads to the politization of charity. In Indonesia, while MORA acts as the formal representative of the Indonesian government, its position is insignificant. It does not have any authority to inspect or sanction fraudulent practices made by charity organizations. This fact causes the unfair distribution of charity funds. Third, the Saudi royal family and its religious establishment are in a position to penetrate the operations of the organizations. They can appoint or remove their officials and replace their managements with new ones that better fit their expectations.

Over its history, the house of al-Saud faced three internal opponents which could threaten its survival: the royal family, secular groups, and religious extremists. ${ }^{28}$ All these opponents opposed the corrupt behavior of the dynasty through their publications, cassettes, and blogs and its alliance with the Western authorities particularly the U.S.. The obvious presence of the U.S. military forces in Saudi territory raised anger among the young Saudi generations whose voices were largely unheard in this authoritarian regime. They demanded larger political participation and freedom of expression. But so far, the state has still been able to maintain social and political order at home even if, to this end, it risked civil rights movements. While maintaining obedience at home, the kingdom suffered from rebels from abroad. Many Saudi civil right activists living abroad launched sharp criticism of the kingdom.

In relation to Saudi charity organizations, factionalism within the royal family which had become Saudi charity organizations' main donor, makes its management unstable. It is an open secret that many royal family members are critical of the kingdom and of the extreme accumulation of wealth in the hands of certain royal family members, while, at the same time, the Muslim population in many parts of the world are living under poor conditions. In the 1980s, when various parts of the Muslim world experienced political conflicts, this criticism came to be transformed into a political ideology. To help their fellow Muslims in Afghanistan, Bosnia, and Chechnya, adherent to this ideology

28 Mamoun Fandy, Saudi Arabia and the Politics of Dissent (New York: Palgrave Macmillan US, 1999), pp. 41-8. 
created semi-state foundations. ${ }^{29}$ Apart from distributing charities to the victims, these foundations engaged in Islamic militancy by supplying Afghan militants with weapons and heavy arsenals to counter Soviet bombardments. Young Afghans whose schools were ruined by the war were sent to Deobandi madrasa in Pakistan and were educated by Wahhabi scholars leading to the rise of the Taliban. For Bosnia and Chechnya, the foundation provided combatants from all over the Muslim world. The combination of charity and Islamic militancy also took place in Southern Thailand and the Southern Philippines. ${ }^{30}$

The involvement of pious but militant patrons eventually took the Saudi international charity organizations to the brink of collapse when its high rank officials were known to have connections with terrorist organizations. This can be seen, among others, in the case of Ahmed al-Amoudi who has family ties with Osama bin Laden. After serving in various countries, he was sent to Southeast Asian countries including Indonesia. In this region, he revitalized the old militant group led by Abu Bakar Ba'asyir and linked it to Al-Qaida. Its task was to reestablish the Islamic state, which was to include greater Southeast Asia. ${ }^{31}$ This organization was reportedly involved in several terror attacks in the region and Western authorities listed the organization as a terrorist group. This fact nonetheless raised a public impression that the Salafis and the extremists, to some extent, are identical.

Apart from global politics, local politics also shaped the transformation of Salafism in Indonesia. In this case, the dominant role of the Hadhrami-Irshadis in distributing Saudi charity funds and its implication to the reproduction of Salafism deserves some attention. In the absence of a central figure after the death of its founder, Sheikh Ahmad Soorkati, Irshadi suffered from conflicts between moderate and puritan groups. Education programs that were the main program of the organization were abandoned. Religious authorities among the Irshadi members were diffused at the hands of petty ulama who, having limited

${ }^{29}$ Benthall and Bellion-Jourdan, The Charitable Crescent, Burr and Collins, Alms for Jihad.

30 See, for instance, Bilveer Singh, The Talibanization of Southeast Asia: Losing the War on Terror to Islamist Extremists (Westport, Conn: Praeger Security International, 2007).

31 Indonesia Backgrounder: Why Salafism and Terrorism Mostly Don't Mix, ICG Report, no. 83 (Brussels: International Crisis Group, 2004). 
resources, tended to compete with each other. Along with the shifting paradigm within the modernists, from politics to social activism, many Irshadi cadres returned to da'wah and joined Persis, which had a revivalist tendency. ${ }^{32}$ In the early 1970s, the first educated Irshadi cadres in the New Order era were born. They were looking for more resources to revitalize the organization and they succeeded after their encounter with Saudi Arabian patrons.

More than any other Irshadi cadre, the role of Farid Okbah was prominent. Born to a Hadhrami family, he was raised in a highly puritan environment. After studying in a Persis madrasa in Malang, East Java, he emerged as a Muslim preacher. He was hostile to local practices usually termed as bid'ah as well as an opponent of the Shiites. It is relevant to mention that a small number of Hadhrami families in Indonesia are Shiite and they established their own religious institutions across the region and over time, tension with Sunni Muslim groups occurred. After the Iranian revolution in 1979, the Iranian government offered various scholarships to Shii students to study in Qum. This mobilization led to more serious conflicts with their Sunni counterparts. Therefore, Okbah was very harsh against Shiism, which he believed not to be an Islamic sect. His anti-Shii rhetoric made him quite popular and he was frequently invited by local Muslim communities to deliver talks on Shiism.

In the early 1990s, under al-Ammar's instructions, Okbah was involved in distributing Saudi Arabian charity funds in Indonesia. To do this, he contacted his colleagues and they created organizations. In Jakarta, they created al-Sofwa, the largest charity organization in Indonesia. In Cirebon, West Java, they created al-Sunnah, led by Umar Sewed, Okbah's junior and an al-Irshad activist. In Salatiga, Central Java, they revived a local Hadhrami school and turned it into a strategic Salafi institution. Thanks to strong financial support, this school is one of the largest Hadhrami schools in the country with a total of 2000 students. It is relevant to say that the school serves as a center of Salafi cadres in Indonesia. Ja'far Umar Thalib, another Irshadi cadre, used to teach at this school before he left and founded his own Salafi group. Okbah also created a yayasan (foundation) in Surabaya, East Java. In this province,

32 Martin van Bruinessen, "Genealogies of Islamic Radicalism in Post-Suharto Indonesia”, South East Asia Research, vol. 10, no. 2 (2002), pp. 117-154. 
Jajang Jahroni

the Irshadhi still enjoyed strong support from local Hadhramis. From Surabaya, the network was expanded to Malang and Jember, in East Java.

\section{G. Changing Urban Landscapes}

Over the last two decades, a number of Islamic organizations and the urban Muslim population have co-existed due to their mutual engagements. It may be said that the urban landscapes have become the places where new Islamization takes place in Indonesia. This process is dubbed "urban santrinization", a sociological term which refers to the rise of urban Muslim communities who are better educated and find themselves in better economic conditions. ${ }^{33}$ They returned religion back into the public sphere, and their presence contributes to a firm Muslim civic association. The Salafis contribute to, and are part of, this development. Given the opportunity to forge social and political structures, they largely participate in the reproduction of public discourses. Through this participation, they expect to be able to influence decision-making processes and the power distribution pertinent to their interests and to maintain their position as a new emerging authority. ${ }^{34}$

Indonesian social landscapes began to change significantly in the 1980s. New urban economic centers emerged in and outside Java. The first Muslim generations were born that were educated under the New Order and they played an important role in shaping public policies. They were actively engaged in social transformation and they distanced themselves from politics. After the imposition of the Pancasila as a sole foundation for political and social organizations in the early 1980s, many Muslim groups shifted from politics to social activism. This shift marked the era of civil Islam, a form of Islam that promoted larger participation in shaping public life. This form of Islam is deemed supportive for the sustainable development of the democratic system.

33 On the rise of urban Muslim communities, see, for instance, Aswab Mahasin, "The Santri Middle Class: An Insider's View", in The Politics of Middle Class Indonesia, ed. by Richard Tanter and Kenneth Ray Young (Clayton, Vic: Monash University, Centre of Southeast Asian Studies, 1990), pp. 138-44.

34 Dale F. Eickelman and James P. Piscatori, Muslim Politics (Princeton, N.J: Princeton University Press, 1996). 


\section{H. The Distribution of Salafi Schools}

The distribution of the Salafi foundations in Indonesia follows various patterns. The first is that it follows urban or semi-urban settlements. This pattern may be seen in Jakarta and in other major cities in the country. The districts of Pasar Minggu and Condet in the South of Jakarta have been Muslim settlements for centuries. There have been local Betawi and Hadhramis who have lived there for a long time. During the colonial period, they were the settlements of the habaib, an honorary title for the descendants of the Prophet Muhammad, where they built madrasa and mosques where the local population learned about Islam. Nowadays these areas have changed dramatically. In the beginning of the New Order, while still being predominantly Muslim settlements, other ethnic and religious groups moved in. Along with the development of greater Jakarta, the local population was forced to sell their land and they moved to the South where they created the new city of Depok. A large number of Salafi communities may be found in these settlements. Many of them run small businesses for instance in fashion, Islamic books, herbal and other medicines, perfume, cosmetics, and all kinds of other items related to urban life. Some sell homemade halal (lawful) food such as cookies, bakso, tofu, and tempeh. They have contributed to the rise of the so-called pro-Sharia economy, a term referring to a number of economic activities such as banking, investment, exchange, insurance, and retail believed to be based on Islamic conjunctions.

The presence of Salafi groups in urban environments attracts many people, among others from among middle class Muslims. After gaining material wellbeing, they need spiritual enrichment. They meet Salafi groups who, having their own TV and radio stations, have better means to reach urban Muslim audiences. Based on my observation, many urban professionals have experienced a feeling of being reborn Muslims after their encounter with Salafi groups. To mark this spiritual journey, they build mosques or renovate old ones in their neighborhoods. This has been the case with Haji Jono, a restaurant owner and active member of al-Hijaz, a Salafi organization in Depok, West Java. Haji Jono is a typical Indonesian businessman who started his business from zero. In the early 1970s, after finishing his high school in Solo, Central Java, he migrated to Jakarta to find a job. After working in various companies, he decided to 
become a bakso (meatball) vendor and after a while he became successful. Then he opened a restaurant and sold a variety of Javanese food. One day, he met members of a Salafi group who came to his restaurant. This meeting marked the start of a new phase in his life. He learned about Islam and he became an active member. He endowed a piece of land for the construction of a madrasa and a mosque. The madrasa specializes in tahfidr, the memorization of the Qur'an, targeting children aged from 5 to 12 from poor family backgrounds.

The penetration of Salafi da'wah among the urban environment was made available by the advancement of technology. First, Salafis use radio, internet and publications through which they could reach urban Muslim audiences. This fact makes scholars currently focus on Islamic cyberspaces, and so far Salafis have one of the largest radio network in the country to promote their da'wah directly to Muslim families who need more programs on Islam. Urban Muslims be they professionals, housewives, women, and men, need information on how Islamic ethics shapes the family, womanhood, marriage, career, children upbringing, et cetera. They also need to know the right procedures for reading the Qur'an, performing their prayers and fasting, and a number of rituals that have become the concerns of every individual Muslim. These needs are, to some extent, met by the abundance of Salafi programs which makes them more familiar with the Salafi form of Islam rather than traditionalist Islam. So every time they need a reference, they will try to find it in Salafi blogs rather than in classical Islamic figh. Second, equally important, Salafi preachers are very active in providing religious services, while many moderate Muslim preachers seem to compete in order to become popular preachers on TV, or to give religious sermons in offices or luxurious apartments from which they get lucrative payment. As a result, the mosques in the neighborhood are empty leading to takeovers by Salafi preachers.

The second pattern of the distribution of Salafi school is that it follows the Irshadi-Hadhrami settlements. As I argued above, al-Irshad was once strongly supported in the coastal areas of Java — from Cirebon in the west (West Java) to Surabaya in east (East Java Province), and in Solo in the center (Central Java) where Salafis had built their institutions. Surabaya and Malang on its Southside have the most important Irshadi 
madrasa. A number of Salafi foundations were established in these cities. Solo should be given some special attention. In this city, Salafism does not only overlap with al-Irshad, it also meets the city's vibrant historical past. In earlier days, Solo had been the center of all kinds of political activism: Islamism, nationalism, and communism. Long before the arrival of the Dutch, it had been the capital of Mataram, the strongest and the largest Muslim kingdom in Java. Solo was and remains the capital of Javanese culture which is syncretic in character. During the celebration of Ashura (the first month of the Islamic year), there are many Javanese cultural events. The heirlooms of the keraton (palace) are exhibited to the public and the venerated white buffalo is paraded around the city.

It is important to note that Solo has one of the largest Salafi foundations in the country. There are at least four big Salafi madrasa in Solo, each having more than 500 students: Imam Bukhari (500), Ibn Taymiyya (600), al-Ukhuwwah (900), and Al-Irshad (1200). These madrasa were founded by former Muslim activists who used to be active in university campuses around Solo. The prominence of these madrasa can be compared with NU madrasa in Jombang and Kediri, the two major traditionalist NU strongholds in East Java. They produce Salafi ustadz they sent across the country as well as to Southeast Asian neighboring countries.

The third pattern is campus-based networking. This pattern is found in Yogyakarta, also called Yogya for short, about 50 kilometer to the southwest of Solo. Yogyakarta is the new capital of Javanese culture and civilization after Solo, also called Surakarta, was defeated by the Dutch. Like Solo, Yogya is also a vibrant place, where syncretic Javanese meet Islamism; Muslims meet Christians; abangan meet santri. The people in Yogya enjoy a great deal of religious freedom and, as a city of education many campuses are distributed all over the city, attracting students from all over Indonesia and other Southeast Asian countries. It is obvious that Salafis have benefitted from the Yogya environment in a number of ways. First of all, they enjoy religious freedom. The local ruler has guaranteed religious freedom for the entire population. Second, Salafis get new recruits from among the Muslim student population. Based on my observation, most if not all of the leading Salafi figures, are former students who eventually left their campuses, as graduates or drop-outs, 
with the purpose of seeking "true" Islam. After the Asas Tunggal policy in 1982 (the imposition of the Pancasila as the sole basis for social and political organizations in Indonesia), many students sought refuge in Salafi groups. They eventually found the ultimate truth in Salafism which offers the middle path between obedience to the rulers and the obligation of advising them. While Salafis have successfully have built their settlements in many places in Java, this does not include Java's northern coastal areas which have remained strongholds of traditionalist Muslim groups. It is worth noting that these northern coastal areas, called Pantura, and stretch from Cirebon in the west (West Java Province), Semarang in the center (Central Java Province), to Tuban and Lamongan in the east (East Java Province), have always been strongholds of traditionalist Muslim groups. In these areas, there are thousands of traditionalist pesantren and religious sanctuaries that have become the main destinations for Muslim pilgrims. The domination of traditionalist Islam in the north coastal areas goes back to the process of Islamization in the eighteenth and nineteenth centuries when Muslim preachers created pesantren to be the prototype of traditional educational institutions. Over time, pesantren networks developed along the lines of family lineages and marriage connections where descendants of local Muslim scholars created new pesantren. Some regions are even dubbed Kota Santri (The City of Students). As a result of this, Salafis were unable to penetrate into these areas. Meanwhile, in West Java, Salafis have established some important madrasa in Bandung and Tasikmalaya. It is obvious that their growth is supported by the puritan culture of the modernist organizations. In both regions are Persis strongholds and many local Muslim scholars remain loyal to this organization. The arrival of the Salafis into the regions in the 1990s revitalized the organization and restored its puritan culture.

The fourth pattern of the distribution of Salafi groups is the targeting of specific areas (sasaran da'wah), to which Salafi organizations sent their preachers to promote Islam to local communities that still adhere to their indigenous religions, or to intercept Christian missionary activities. During the New Order, Christianization had been a major concern of various Islamic organizations such as DDII, and this has now been taken over by Salafi organizations, which in many respects share the same spirit. This is particularly true for the Wahdah, which regularly 
sent preachers to remote areas in Central and Eastern Indonesia such as Kalimantan, Maluku, and Papua. In East Kalimantan, Salafis, together with Hidayatullah (established in 1973), an organization focused on education, target Balikpapan and Samarinda, the two major cities in the province which have experienced rapid economic growth. In Sumatra, Salafis create many madrasa in Riau Province, concentrated in Pekanbaru, the capital of the province. There are eight Salafi madrasa/schools in this province with more than 1000 students. For decades, this province has been one of the most important migration areas. Meanwhile, in Papua, many Laskar Jihad ex-combatants who waged jihad in Maluku in the 2000s, turned preachers and teachers and established madrasa in Sorong, one of the fastest growing cities in the region. ${ }^{35}$

It is important to say that the target areas outside Java largely overlap with, and use, migration patterns. Over decades, people from overpopulated Java have migrated to regions outside Java to look for a better life. They work in commerce, plantations, and mining. In these new places they create mosques and madrasa, and their need for religious teachers is met by Muslim organizations in Java. The DDII is very concerned with Islamic propagation in transmigration areas. When the Salafis emerged in the 1990s, they followed this pattern. Peripatetic Salafi filled the positions of religious teachers in these areas, providing Qur'anic learning for migrant families, a job hardly ever done by mainstream Muslim organizations. It is thus pretty obvious that the presence of Salafis outside Java is a continuation of Salafism in Java and has nothing to do with the local Muslim population. It is often said in the local communities that Salafis are pendatang (newcomers) from Java, not members of the local population.

\section{Concluding Remarks}

The institutionalization of Indonesian Salafi groups will not be possible without the support of Saudi Arabia. Through its international bodies, Saudi channeled donations to the Salafi groups in Indonesia by which they create madrasa and mosques. This is made to counter Iran's propaganda which at the same time campaigned to export its Shii revolution. Through madrasa and mosques, the Salafis are able to

35 Ustadz Badruddin, interview (17 Feb 2011). 
convey their message to Indonesian larger audience. LIPIA is the first and the foremost Saudi institution from which Salafism is transmitted to Indonesia. Its students and alumni have played significant roles in transmitting this model of Islam to Indonesian Muslim groups.

Urban middle class Muslims have taken benefits from the Salafi da'wa as they learn Islam and how to become good Muslims. On the contrary, urban middle class Muslims have given various donations for the continuation of the da'wa. The birth of urban middle class is made possible by changing Indonesian social and religious landscapes. They are the first educated Muslim generation born thanks to the education project initiated by the Suharto's New Order. They experienced the socalled objectification as they raised fundamental question concerning their Muslim identities.

The Salafis establish yayasan (foundation) as a means to distribute charities and to extend network with local Muslim groups. In the late 1990s, the Salafi yayasan were given opportunities to create network with local Muslim groups and to select students to be sent to Saudi universities. The practice of charity within the Salafi groups have been very informal which makes it overlaps with politics that sometimes go far beyond the purpose of charities. Charities are used to support other Muslim fellows in other parts of the world not only as an act of piety but as a political manuever as happens in many parts of the Muslim world.

The roles of Hadhramai in distributing Saudi charities are visible. They are the mediators between the Saudi state and local Muslim communities. As a result, there have been a number of Hadhrami figures behind this transformation. With these charities, they are able to establish Islamic boarding schools across the country. Most of these boarding schools are spred in Java as weel as outside Java. This particularly occur in Yogya and Solo, two cities in Java which have strong puritan culture. So the arrival of the Salafi groups revive this culture. Their presence, however, do not cover the stronghold of the traditionalist Nahdhatul Ulama in northern Java areas. Outside Java, they revive the patterns previously made by the modernist Muslim organizations which attempt to intercept the Christian missionary activities. 
Saudi Arabia Charity and the Institutionalization of Indonesian Salafism

\section{BIBLIOGRAPHY}

Abaza, Mona, "M. Asad Shahab: A Portrait of an Indonesian Hadrami Who Bridged the Two World", in Southeast Asia and the Middle East: Islam, Movement, and the Longue Durée, ed. by Eric Tagliacozzo, Singapore: NUS Press, 2009.

Azra, Azyumardi, "Hadrāmī scholars in the Malay-Indonesian Diaspora: A Preliminary Study of Sayyid 'Uthmān”, Studia Islamika, vol. 2, no. 2, 1995 [https://doi.org/10.15408/sdi.v2i2.833].

Benthall, J., "The Overreaction against Islamic Charities", ISIM Review, vol. 20 , no. 1, 2007, pp. 6-7.

Benthall, Jonathan and Jérôme Bellion-Jourdan, The Charitable Crescent: Politcs of Aid in the Muslim World, London; New York: I.B. Tauris, 2003.

van Bruinessen, Martin, "Genealogies of Islamic Radicalism in PostSuharto Indonesia":, South East Asia Research, vol. 10, no. 2, 2002, pp. 117-154 [https://doi.org/10.5367/000000002101297035].

----, "Ghazwul Fikri or Arabization? Indonesian Muslim Responses to Globalization", in Southeast Asian Muslims in the Era of Globalization, ed. by Ken Miichi and Omar Farouk, Tokyo: Japan International Cooperation Agency Research Institute (JICA-RI), 2013, pp. 47-70 [https://doi.org/10.1057/9781137436818_4].

Burr, Millard and Robert O. Collins, Alms for Jihad: Charity and Terrorism in the Islamic World, Cambridge: Cambridge University Press, 2006.

Camelin, Sylvaine, "Reflections on the Sytem of Social Stratification in Hadhramaut", in Hadhrami Traders, Scholars and Statesmen in the Indian Ocean, 1750s to 1960s, ed. by Ulrike Freitag and William G. ClarenceSmith, Leiden, New York and Koln: Brill, 1997.

Casanova, José, Public Religions in the Modern World, Chicago: University of Chicago Press, 1994.

Clarence-Smith, William G., "Hadhramaut and the Hadhrami Diaspora in the Modern Colonial Era: An Introductory Survey", in Hadhrami Traders, Scholars and Statesmen in the Indian Ocean, 1750s to 1960s, ed. by Ulrike Freitag and William G. Clarence-Smith, Leiden, New York 
and Koln: Brill, 1997, pp. 1-18.

Eickelman, Dale F. and James P. Piscatori, Muslim Politics, Princeton, N.J: Princeton University Press, 1996.

Fandy, Mamoun, Saudi Arabia and the Politics of Dissent, New York: Palgrave Macmillan US, 1999.

Freitag, Ulrike and William G. Clarence-Smith (eds.), Hadhrami Traders, Scholars and Statesmen in the Indian Ocean, 1750s to 1960s, Leiden, New York and Koln: Brill, 1997.

Hasan, Noorhaidi, Laskar Jihad: Islam, Militancy, and the Quest for Identity in Post-New Order Indonesia, Ithaca: Cornell University Press, Southeast Asia Program Publications at Cornell University, 2006.

Hefner, Robert W., Civil Islam: Muslims and Democratization in Indonesia, Princeton: Princeton University Press, 2000.

Husin, Asna, "Philosophical and Sociological Aspects of Da'wah: A Study of Dewan Dakwah Islamiyah Indonesia", PhD. Dissertation, New York: Columbia University, 1998.

'Amr, Ziyād Abū, Islamic Fundamentalism in the West Bank and Gaza: Muslim Brotherhood and Islamic Jihad, Bloomington: Indiana University Press, 1994.

Indonesia Backgrounder: Why Salafism and Terrorism Mostly Don't Mix, ICG Report, no. 83, Brussels: International Crisis Group, 2004.

Latief, Hilman, "Islamic Charities and Social Activism: Welfare, Dakwah and Politics in Indonesia", PhD. Dissertation, Utrecht: Utrecht University, 2012.

Mahasin, Aswab, "The Santri Middle Class: An Insider's View", in The Politics of Middle Class Indonesia, ed. by Richard Tanter and Kenneth Ray Young, Clayton, Vic: Monash University, Centre of Southeast Asian Studies, 1990.

Mobini-Kesheh, Natalie, The Hadrami Awakening: Community and Identity in the Netherlands East Indies, 1900-1942, Ithaca: Cornell Southeast Asian Program Publications-Cornell University Press, 1999.

Mujiburrahman, Feeling Threatened: Muslim-Christian Relations in Indonesia's New Order, Amsterdam: Amsterdam University Press, 2006.

Singh, Bilveer, The Talibanization of Southeast Asia: Losing the War on Terror 
Saudi Arabia Charity and the Institutionalization of Indonesian Salafism

to Islamist Extremists, Westport, Conn: Praeger Security International, 2007.

Slama, Martin, "Translocal Networks and Globalisation within Indonesia: Exploring the Hadhrami Diaspora from the Archipelago's NorthEast", Asian Journal of Social Science, vol. 39, no. 2, Brill, 2011, pp. 238-57 [https://doi.org/10.1163/156853111X565904].

Tagliacozzo, Eric (ed.), Southeast Asia and the Middle East: Islam, Movement, and the Longue Durée, Singapore: NUS Press, 2009.

Wahid, Din, "Nurturing Salafi Manhaj: A Study of Salafi Pesantren in Contemporary Indonesia", PhD. Dissertation, Utrecht: Utrecht University, 2014. 
Jajang Jahroni 